\title{
Secretagogue-induced $\mathrm{Ca}^{2+}$ oscillations in isolated canine gastric chief cells
}

\author{
Yasuhiro Tsunoda ', John A. Williams ${ }^{1,2}$ and John DelValle ${ }^{2}$ \\ ' Department of Physiology, The University of Michigan, Ann Arbor, MI (U.S.A.) and ' Department of Internal Medicine, \\ The University of Michigan, Ann Arbor, MI (U.S.A.)
}

(Received 27 July 1990)

Key words: $\mathrm{Ca}^{2+}$ spike; Fura-2; Chief cell; (Canine gastric mucosa)

Agonist-induced changes in cytoplasmic free $\mathrm{Ca}^{2+}$ concentration $\left(\left[\mathrm{Ca}^{2+}\right]_{i}\right)$ of isolated canine gastric chief cells were evaluated by microspectrofluorometry of superfused fura-2 loaded cells. Application of high concentrations of carbachol $\left(\mathrm{CCh}, 10^{-5} \mathrm{M}\right)$ or cholecystokinin octapeptide $\left(10^{-8} \mathrm{M}\right)$ resulted in biphasic $\mathrm{Ca}^{2+}$ mobilization comprising an initial large transient followed by a small sustained elevation above the prestimulation level. Submaximal concentrations of CCh $\left(10^{-6} \mathrm{M}\right)$ or cholecystokinin $\left(10^{-9} \mathrm{M}\right)$ led to either a transient series of large amplitude $\mathrm{Ca}^{2+}$ spike(s) or a higher frequency of sustained $\mathrm{Ca}^{2+}$ oscillations of smaller amplitude. Cholecystokinin at $10^{-10} \mathrm{M}$ induced only sustained $\mathrm{Ca}^{2+}$ oscillations. Elimination of $\mathrm{Ca}^{2+}$ from the medium had no immediate effect on oscillations indicating an intracellular source of $\mathrm{Ca}^{2+}$. Thus the $\mathrm{Ca}^{2+}$ signalling mode in chief cells is dependent on agonist concentrations.

Pepsinogen secretion from mammalian gastric chief cells is believed to be regulated by an increase in cytoplasmic free $\mathrm{Ca}^{2+}$ concentration $\left(\left[\mathrm{Ca}^{2+}\right]_{i}\right)$ following stimulation by either a peptidergic (cholecystokinin) or a cholinergic pathway [1-5]. The pattern of $\left[\mathrm{Ca}^{2+}\right]_{i}$ increase most commonly reported has been a rapid but transient increase, followed by a small sustained elevation above the prestimulation level. The first component originates from intracellular stores and is believed to be mediated by inositol 1,4,5-trisphosphate $\left(\mathrm{IP}_{3}\right)$ [6]. The second component is due to $\mathrm{Ca}^{2+}$ entry from the extracellular space, although its control is still unclear. Previous studies utilizing quin 2, fura-2 and aequorin as probes have been carried out in rabbit gastric glands or isolated chief cells [1-3] and guinea pig isolated chief cells $[4,5]$ that were suspended in a stirred cuvette. This approach, however, may fail to show transient changes in $\mathrm{Ca}^{2+}$ mobilization among individual cells due to the integration of the fluorescence signal over a large number of cells. Recently, it has become possible to measure $\left[\mathrm{Ca}^{2+}\right]_{i}$ in individual cells utilizing microspectrofluorometry or digital imaging microscopy of fura-2, thereby resolving events that would be masked when recording from a population of cells. A preliminary study of

Correspondence: J. DelValle, 6520 MSRBI, $1150 \mathrm{~W}$. Medical Center Drive, The University of Michigan Medical Center, Ann Arbor, MI 48109-0682 U.S.A. individual guinea pig chief cells showed a $\left[\mathrm{Ca}^{2+}\right]_{i}$ increase but only a single high concentration of cholecystokinin octapeptide $\left(10^{-8} \mathrm{M}\right)$ was evaluated [7]. In the present study, we have observed that lower and presumably more physiological concentrations of carbachol and cholecystokinin led to periodic and repetitive oscillations in $\left[\mathrm{Ca}^{2+}\right]_{i}$ in individual canine gastric chief cells.

Gastric chief cells were isolated from adult canine fundic mucosa using sequential exposure to collagenase and ethylenediamine tetraacetic acid (EDTA) and enriched to greater than $70 \%$ homogeneity by counterflow elutriation as previously described $[8,9]$. Contaminating cells consisted primarily of mucous containing cells. Isolated chief cells $\left(2 \cdot 10^{6}\right)$ were loaded with fura-2 acetoxymethyl ester (Molecular Probes, Eugene, OR) using methods previously described [10,11]. A physiological salt solution (PSS) containing (in $\mathrm{mM}$ ) $137 \mathrm{NaCl}$, $4.7 \mathrm{KCl}, 0.56 \mathrm{MgCl}_{2}, 1.28 \mathrm{CaCl}_{2}, 1.0 \mathrm{NaH}_{2} \mathrm{PO}_{4}, 10.0$ Hepes- $\mathrm{NaOH}, 0.1 \%$ bovine serum albumin ( $\mathrm{pH}$ 7.4) was used. For calcium-free experiments, $\mathrm{CaCl}_{2}$ was replaced with $1 \mathrm{mM}$ EGTA. Measurement of fura-2 fluorescence and calculation of $\left[\mathrm{Ca}^{2+}\right]_{i}$ on single chief cells were performed as previously described $[10,11]$ using a superfusion system and a Spex dual excitation wavelength fluorometer coupled to a Nikon Diaphot microscope.

The average resting $\left[\mathrm{Ca}^{2+}\right]_{\mathrm{i}}$ determined in 52 individual canine chief cells was $76 \pm 5 \mathrm{nM}$ when $\mathrm{Ca}^{2+}(1.28$ $\mathrm{mM}$ ) was present in the medium. Stimulation with a maximal concentration of the muscarinic cholinergic 
agonist carbachol $\left(\mathrm{CCh}, 10^{-5} \mathrm{M}\right)$ caused a rapid increase in $\left[\mathrm{Ca}^{2+}\right]_{i}$ to $377 \pm 60 \mathrm{nM}$ followed by a fall within 3-4 min to a sustained plateau of $\left[\mathrm{Ca}^{2+}\right]_{i}$ about $40 \mathrm{nM}$ above the prestimulation level (Fig. 1A). The peak height of the initial large transient of $\left[\mathrm{Ca}^{2+}\right]_{i}$ in the absence of medium $\mathrm{Ca}^{2+}$ (Fig. 1B) was $330 \pm 41$ $\mathrm{nM}$ from a basal $\left[\mathrm{Ca}^{2+}\right]_{\mathrm{i}}$ of $74 \pm 15 \mathrm{nM}(n=7)$. This increase was not significantly different from that determined in the presence of medium $\mathrm{Ca}^{2+}$. However, the sustained plateau of $\left[\mathrm{Ca}^{2+}\right]_{i}$ declined almost to the prestimulation level when medium $\mathrm{Ca}^{2+}$ was eliminated (Fig. 1B). Decreasing the $\mathrm{CCh}$ concentration to a submaximal level $\left(10^{-6} \mathrm{M}\right)$ resulted in three different types of $\mathrm{Ca}^{2+}$ mobilization (Table I). Some cells showed a similar $\mathrm{Ca}^{2+}$ transient to that induced by $10^{-5} \mathrm{M} \mathrm{CCh}$. In most cells $(12 / 16)$ oscillations in $\left[\mathrm{Ca}^{2+}\right]_{i}$ were induced. In seven cells, oscillations in $\left[\mathrm{Ca}^{2+}\right]_{\mathrm{i}}$ were of decreasing amplitude and stopped within 10-15 min (Fig. 1C). In other cells oscillations were more rapid and sustained occurring on top of a baseline increase in $\left[\mathrm{Ca}^{2+}\right]_{i}$ (fig. 1D). The effects of low doses of $\mathrm{CCh}$ were rapidly reversible upon its removal from the superfusate and could be reinduced. The threshold $\mathrm{CCl}_{\text {chentra- }}$ tion for evoking $\mathrm{Ca}^{2+}$ oscillations was $2.5 \cdot 10^{-7} \mathrm{M}$; $10^{-7} \mathrm{M} \mathrm{CCh}$ was unable to affect $\left[\mathrm{Ca}^{2+}\right]_{i}$ in nine cells examined.

Stimulation of chief cells with submaximal concentrations of the peptidergic hormone cholecystokinin octapeptide, $\left(10^{-9} \mathrm{M}\right)$ also induced somewhat similar types of $\mathrm{Ca}^{2+}$ signaling including large $\mathrm{Ca}^{2+}$ transients, transient oscillations (Fig. 2A) and sustained oscillations (Fig. 2B). When the $\left[\mathrm{Ca}^{2+}\right]_{i}$ peak height was relatively high $(250 \mathrm{nM})$ and transient, the spike frequency was slow. In the case of sustained oscillations, the peak $\left[\mathrm{Ca}^{2+}\right]_{i}$ height was smaller $(160 \mathrm{nM})$ but the frequency was faster averaging $1.8 \mathrm{times} / \mathrm{min}$ (Table I). A significant reciprocal relationship was observed between the oscillation amplitude and the frequency when individual cells were stimulated by submaximal concentration of agonist (cholecystokinin; $10^{-9} \mathrm{M}$, $\left.\mathrm{CCh} ; 10^{-6} \mathrm{M}\right)$ with a correlation coefficient of -0.61 $(P<0.02, n=12$ cells). A decrease in cholecystokinin concentration to $10^{-10} \mathrm{M}$ resulted in small but regular sized $\mathrm{Ca}^{2+}$ oscillations (Fig. $2 \mathrm{C}$ ). In this case the oscillation amplitude averaged $80 \mathrm{nM}$ above the basal increase in $\left[\mathrm{Ca}^{2+}\right]_{i}$ and frequency averaged 0.7 times $/ \mathrm{min}$. With the lower concentrations of stimulants there was a longer latency in evoking the first $\mathrm{Ca}^{2+}$ spike of up to 60 s. Removal of extracellular $\mathrm{Ca}^{2+}$ to a concentration less than resting $\left[\mathrm{Ca}^{2+}\right]_{i}$ had no immediate effect on $\mathrm{Ca}^{2+}$ oscillations (Fig. 2C) as examined in five cells. Thus the primary source utilized for $\mathrm{Ca}^{2+}$ oscillations was intracellular. Increasing cholecystokinin concentration to the maximal level $\left(10^{-8} \mathrm{M}\right)$ resulted in an immediate large rise in $\left[\mathrm{Ca}^{2+}\right]_{i}$ to $599 \mathrm{nM}$ followed by a fall within 3-4 min to a plateau of $30 \mathrm{nM}$ above the
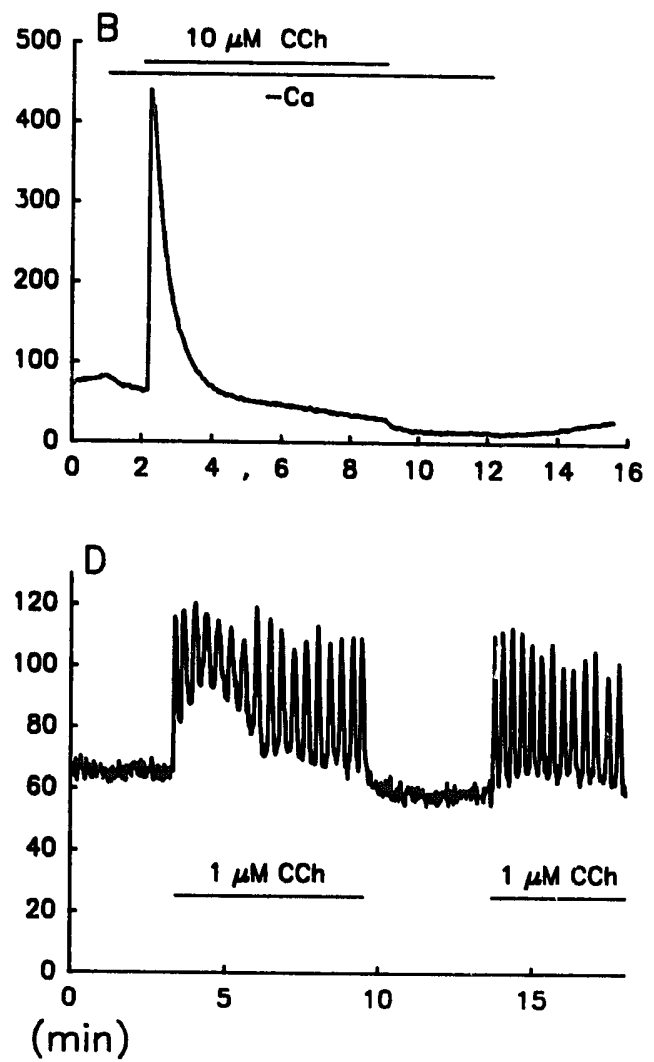

Fig. 1. Cytoplasmic free $\mathrm{Ca}^{2+}$ concentration $\left(\left[\mathrm{Ca}^{2+}\right]_{i}\right)$ in individual canine gastric chief cells stimulated by various concentrations of carbachoi (CCh). Each panel is representative of 7-11 separate experiments. Abbreviations used: - Ca, Calcium-free PSS. 
TABLE I

$\mathrm{Ca}^{2+}$ signaling mode induced by various concentrations of carbachol (CCh) and cholecystokinin octapeptide (CCK)

Amplitude levels were determined in a peak state by subtracting basal $\left[\mathrm{Ca}^{2+}\right]_{i}$ in each individual cell. The frequency of oscillation was calibrated by the number of $\mathrm{Ca}^{2+}$ spikes occurring 10-30 min after cell stimulation. Values presented are means \pm S.E.

\begin{tabular}{|c|c|c|c|}
\hline $\begin{array}{l}\text { Agonist } \\
\text { (M) }\end{array}$ & $\begin{array}{l}\text { Mode of } \\
\mathrm{Ca}^{2+} \text { signalling } \\
\text { (No. of cells) }\end{array}$ & $\begin{array}{l}\text { Peak }\left[\mathrm{Ca}^{2+}\right]_{i} \\
\text { amplitude from } \\
\text { basal (nM) }\end{array}$ & $\begin{array}{l}\text { Frequency of } \\
\text { oscillation } \\
\text { (times/min) }\end{array}$ \\
\hline \multicolumn{4}{|l|}{$\mathrm{CCh}$} \\
\hline $1 \times 10^{-5}$ & large transient $(9 / 9)$ & $295 \pm 59$ & - \\
\hline \multirow[t]{3}{*}{$1 \times 10^{-6}$} & $\begin{array}{l}\text { large transient }(4 / 16) \\
\text { transient oscillations }\end{array}$ & $278 \pm 54$ & - \\
\hline & $\begin{array}{l}(7 / 16) \\
\text { sustained oscillations }\end{array}$ & $172 \pm 42$ & $0.47 \pm 0.10$ \\
\hline & $(5 / 16)$ & $71 \pm 22$ & $2.66 \pm 0.49$ \\
\hline \multicolumn{4}{|l|}{ CCK } \\
\hline $1 \times 10^{-8}$ & large transient $(5 / 5)$ & $507 \pm 72$ & - \\
\hline \multirow[t]{3}{*}{$1 \times 10^{-9}$} & $\begin{array}{l}\text { large transient }(4 / 12) \\
\text { transient oscillations }\end{array}$ & $268 \pm 67$ & - \\
\hline & $\begin{array}{l}(5 / 12) \\
\text { sustained oscillations }\end{array}$ & $183 \pm 31$ & $0.64 \pm 0.16$ \\
\hline & $(3 / 12)$ & $86 \pm 24$ & $1.80 \pm 0.10$ \\
\hline \multirow[t]{2}{*}{$1 \times 10^{-10}$} & sustained oscillations & & \\
\hline & $(5 / 5)$ & $80 \pm 22$ & $0.72 \pm 0.11$ \\
\hline
\end{tabular}

prestimulation level (Fig. 2D). The related peptide, gastrin $\left(10^{-8} \mathrm{M}\right)$, did not produce any significant change in $\left[\mathrm{Ca}^{2+}\right]_{i}$ in 5 cells. Therefore, the receptor involved appears to be a cholecystokinin preferring rather than a gastrin receptor. Bombesin $\left(10^{-8}\right.$ and $\left.10^{-7} \mathrm{M}\right)$ and histamine $\left(10^{-4} \mathrm{M}\right)$ were also without effect on $\left[\mathrm{Ca}^{2+}\right]_{i}$ in six cells (data not shown).

Intracellular free $\mathrm{Ca}^{2+}$ appears to play a central role in the control of chief cell secretion [1-5]. Calcium ionophores stimulate pepsinogen secretion, EGTA inhibits long-term secretion and digitonin permeabilized gastric glands secrete pepsinogen in response to an increase in $\mathrm{Ca}^{2+}$ concentration in the medium $[12,13]$. With the advent of fluorescent probes for $\mathrm{Ca}^{2+},\left[\mathrm{Ca}^{2+}\right]_{i}$ has been measured in chief cells and shown to increase in response to some peptidergic secretagogues, most noticeably, cholecystokinin, and also in response to cholinergic agonists. Studies of $\left[\mathrm{Ca}^{2+}\right]_{i}$ in a population of chief cells have previously been carried out primarily in isolated guinea pig chief cells $[4,5,7]$ and rabbit gastric glands $[1,3]$. In these studies basal $\left[\mathrm{Ca}^{2+}\right]_{i}$ was $200 \mathrm{nM}$ in guinea pig and $150 \mathrm{nM}$ in rabbit, and increased to $500 \mathrm{nM}$ and $500-800 \mathrm{nM}$, respectively, after cell stimulation. The $\left[\mathrm{Ca}^{2+}\right]_{i}$ increase was dependent on agonist concentration and showed an initial large transient, which declined after 3-5 min, followed by a small sustained plateau above the prestimulation level. The initial large transient and the following sustained plateau originated from intracellular and extracellular $\mathrm{Ca}^{2+}$, respectively.

In the present study we used microspectrofluorometry to evaluate $\left[\mathrm{Ca}^{2+}\right]_{\mathrm{i}}$ in single canine chief cells. When
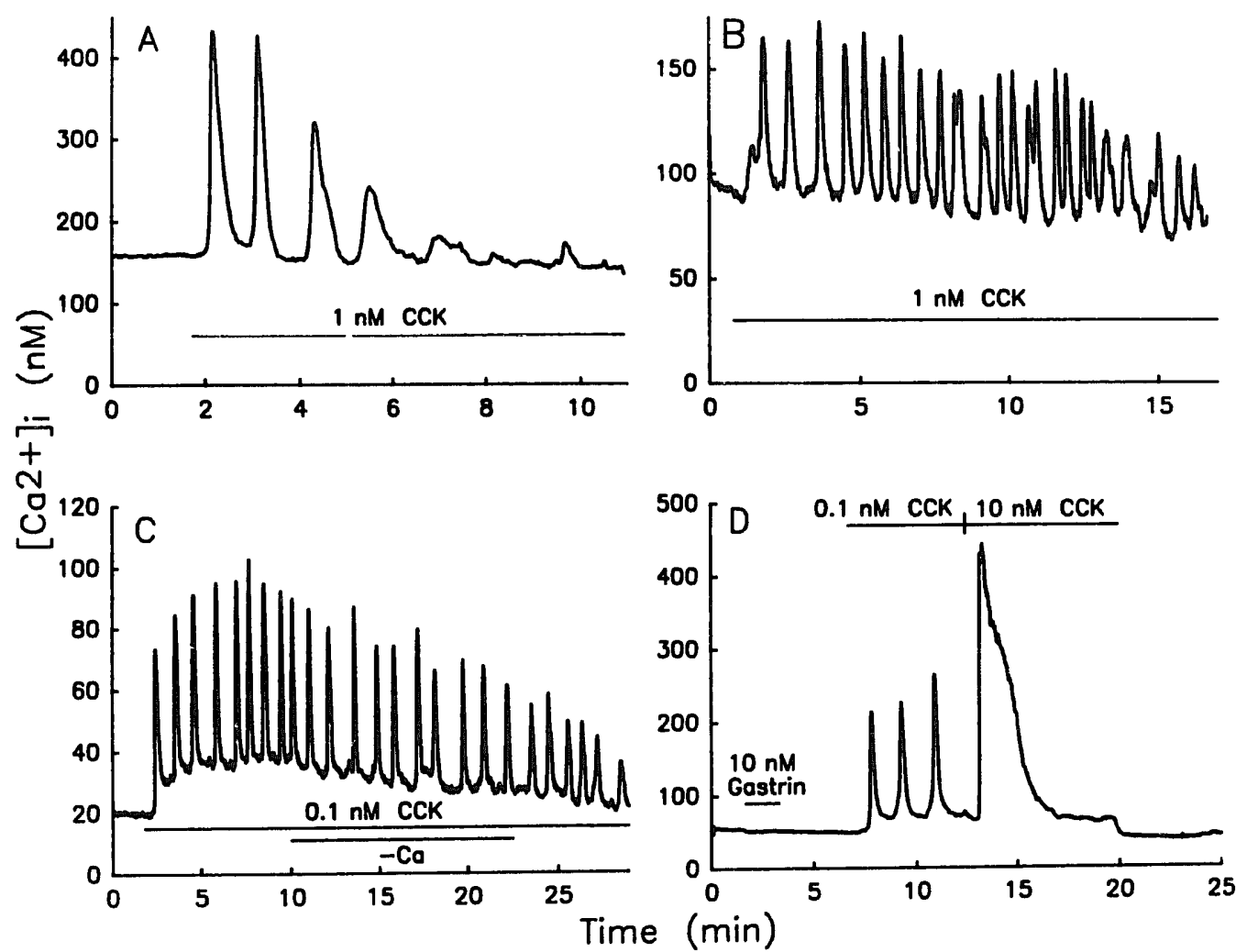

Fig. 2. $\left[\mathrm{Ca}^{2+}\right]_{i}$ mobilization pattern in chief cells induced by various concentrations of cholecystokinin octapeptide (CCK). Each panel is representative of 5-10 separate experiments. 
we used a high concentration of secretagogue $(\mathrm{CCh}$; $10^{-5} \mathrm{M}$, cholecystokinin; $10^{-8} \mathrm{M}$ ) we observed a large transient $\left[\mathrm{Ca}^{2+}\right]_{\mathrm{i}}$ increase similar to previous population studies. Using lower concentrations of secretagogues, however, we observed transient spikes or oscillations of $\left[\mathrm{Ca}^{2+}\right]_{\mathrm{i}}$. These oscillations had not been seen in previous studies of gastric chief cells. Of interest, at intermediate secretagogue concentrations we observed some cells showing larger increases which then became smaller and even disappeared over a 10-15 min period. Another pattern observed was that of small amplitude and high frequency $\mathrm{Ca}^{2+}$ oscillations similar to those which have been observed in various cell types [14-16]. The repetitive oscillations observed in gastric chief cells are generally similar to those observed in pancreatic acinar cells which respond to cholecystokinin with an oscillation frequency of $1.5 \mathrm{times} / \mathrm{min}$ [11]. In other cells responding to a variety of stimuli, oscillations occur from 0.3 to 12 times/min [14-16]. Similar to almost all other non-excitable cells, the primary sources of $\mathrm{Ca}^{2+}$ for oscillations in canine chief cells was intracellular.

In guinea pig isolated chief cells, cholecystokinin stimulates pepsinogen secretion over the concentration range of $10^{-11}-10^{-7} \mathrm{M}$ with an approximate $\mathrm{EC}_{50}$ of $10^{-10} \mathrm{M}$ [17]. Also, $\mathrm{CCh}$ stimulates pepsinogen secretion over the concentration range of $3 \cdot 10^{-7}-10^{-3} \mathrm{M}$ with an approximate $\mathrm{EC}_{50}$ of $10^{-6} \mathrm{M}$ [17]. Thus the concentrations of secretagogues which cause $\mathrm{Ca}^{2+}$ oscillations, are close to the $\mathrm{EC}_{50}$ for pepsinogen release. Gastrin $\left(10^{-8} \mathrm{M}\right)$, which was unable to affect $\left[\mathrm{Ca}^{2+}\right]_{i}$, has been reported not to induce pepsinogen secretion in primary monolayer cultured canine chief cells while cholecystokinin $\left(10^{-8} \mathrm{M}\right)$ induced pepsinogen secretion in the same species preparation [18]. In contrast, canine parietal cells secrete acid equally well in response to both cholecystokinin and gastrin [18], suggesting that the cholecystokinin receptor on chief cells differs from the closely related gastrin receptor on parietal cells. Histamine, which was also incapable of mobilizing $\left[\mathrm{Ca}^{2+}\right]_{i}$ in the present study, induces pepsinogen secretion in canine chief cells, probably through cyclic AMP [17].

In summary, the $\mathrm{Ca}^{2+}$ signaling mode in response to carbachol and cholecystokinin show different patterns depending on the concentration of secretagogues. At what are presumed physiologic levels of secretion, many cells shows $\mathrm{Ca}^{2+}$ oscillations. These repetitive transient increases in $\left[\mathrm{Ca}^{2+}\right]_{i}$ may play a role in the control of pepsinogen secretion.

\section{Acknowledgements}

We are grateful to Refkije Jakupi for her technical assistance. These studies were supported in part by the Michigan Gastrointestinal Peptide Research Center (P30-DK-34933) and by NIH Grants K08-DK-01823 (JDV) an DK-41122 (JAW).

\section{References}

1 Muallem, S., Fimmel, C.J., Pandol, S.J. and Sachs, G. (1986) J. Biol. Chem. 261, 2660-2667.

2 Chew, C.S. and Brown, M.R. (1986) Biochim. Biophys. Acta 888, 116-125.

3 Chew, C.S. (1986) Am. J. Physiol. 250, G814-G823.

4 Tsunoda, Y. and Wider, M.D. (1987) Biochim. Biophys. Acta 905, 118-124.

5 Tsunoda, Y., Takeda, H., Otaki, T., Asaka, M., Nakagaki, I. and Sasaki, S. (1988) Biochim. Biophys. Acta 941, 83-101.

6 Berridge, M.J. and Irvine, R.F. (1984) Nature 312, 315-321.

7 Tsunoda, Y., Yodozawa, S. and Tashiro, T. (1988) Cell Struct. Funct. 13, 407-415.

8 Soll, A.H. (1978) J. Clin. Invest. 61, 370-380.

9 Ayalon, A., Sanders, M.J., Thomas, L.P., Amirian, D.A. and Soll, A.H. (1982) Proc. Natl. Acad. Sci. USA 79, 7009-7013.

10 Stuenkel, E.L., Tsunoda, Y. and Williams, J.A. (1989) Biochem. Biophys. Res. Commun. 158, 863-869.

11 Tsunoda, Y., Stuenkel, E.L. and Williams, J.A. (1990) Am. J. Physiol. 258, C147-C155.

12 Raufman, J-P., Berger, S., Cosowsky, L. and Straus, E. (1986) Biochim. Biophys. Res. Commun. 137, 281-285.

13 Norris, S.H. and Hersey, S.J. (1985) Am. J. Physiol. 249, G408G415.

14 Woods, N.M., Cuthbertson, K.S.R. and Cobbold, P.H. (1986) Nature (London) 319, 600-602.

15 Berridge, M.J. and Galione, A. (1988) FASEB J. 2, 3074-3082.

16 Jacob, R., Merritt, J.E., H d Rink, T.J. (1988) Nature $335,40-45$.

17 Raufman, J-P., Sutliff, V.E., Kasbekar, D.K., Jensen, R.T. and Gardner, J.D. (1984) Am. J. Physiol. 247, G95-G104.

18 Sanders, M.J., Amirian, D.H., Ayalon, A. and Soll, A.H. (1983) Am. J. Physiol. 245, G641-G646. 